\title{
sciendo
}

\section{UDDER AND CLAW-RELATED HEALTH TRAITS IN SELECTION OF CZECH HOLSTEIN COWS*}

\author{
Zuzana Krupová^, Ludmila Zavadilová, Marie Wolfová, Emil Krupa, Eva Kašná, Petr Fleischer \\ Institute of Animal Science, Přátelství 815, 10400 Prague - Uhříněves, Czech Republic \\ •Corresponding author: krupova.zuzana@vuzv.cz
}

\begin{abstract}
The aim of the study was to investigate the impact of the implementation of new health traits into the breeding objective and selection criteria for Czech Holstein cows on the genetic selection response in the breeding objective traits. Incidence of overall claw diseases was included into the current breeding objective for cows (11 traits together). Three traits that indicated claw health (incidence of claw diseases overall and infectious and non-infectious claw diseases) and incidence of clinical mastitis were successively added to the current selection criteria in a cow selection index (a maximum of 19 traits). Selection responses in the breeding objective traits were estimated by applying the general principles of the selection index theory. The required genetic variances for the new traits, the economic weights for all breeding objective traits and the genetic correlations among the selection index traits were estimated within this study. The marginal economic weights, which were calculated for two-year-old cows by applying a bioeconomic model with implemented gene flow, were -193 and $-168 €$ per case for clinical mastitis and overall claw disease incidence, respectively. Using the comprehensive selection index with 19 traits, the reduction in the incidence of both udder and claw diseases was calculated to be 0.004 cases per cow per year. At the same time, a more favourable genetic selection response was obtained for other functional traits, e.g., $+0.020 \%$ for cow conception rate and $+\mathbf{0 . 0 1 0}$ years for productive life of cow (which represented the profit of $67 €$ and $367 €$ per herd and per year, respectively) when compared to the current index. Based on this study, a direct selection of cows for claw and udder health is nowadays recommended to improve the health status of herds and economics in production systems.
\end{abstract}

Key words: dairy cattle, foot and claw health, clinical mastitis, genetic response

Traits related to udder, claw and foot health have become a new focus in dairy cattle breeding in recent decades mainly due to their impact on the quantity and quality of milk, on animal welfare and on the overall dairy-farm profitability (Kargo et al., 2014; Martin et al., 2018; Heringstad et al., 2018). Clinical mastitis is usu-

*The study was funded by the Ministry of Agriculture of the Czech Republic MZE-RO0718 V003 and QJ1510144. 
ally defined as an inflammation of the udder resulting from invasion of pathogenic microorganisms. Claw health traits are usually grouped according to etiology and pathogenesis (Greenough et al., 1997) to represent the most frequent disorders. Infectious diseases predominantly affect the skin and are associated with environmental hygiene (digital and interdigital dermatitis, interdigital phlegmon, and heel horn erosion). Non-infectious diseases present as claw horn disorders and lesions (ulcers, sole hemorrhage, and white line disease) and are primarily caused by a combination of metabolic and mechanical factors (Greenough et al., 1997). In addition to precision management, regular hoof treatment and veterinary care in the herds, the genetic improvement of health traits is used as valuable tool to obtain progress in the health status of dairy cows. Including health traits in the breeding objectives is also emphasized to achieve genetic progress in other functional traits (Martin et al., 2018). Therefore, genetic parameters and economic weights have been estimated for health traits to enhance the existing selection indices in some countries (Stott et al., 2005; van der Linde et al., 2010; Heringstad et al., 2018).

In the current breeding objective for Czech Holstein cattle, altogether 10 production and functional traits are involved (with clinical mastitis as the only direct health trait). In the sire selection index, the 17 criteria are grouped into milk production, udder health (represented by somatic cell score), reproduction, exterior, and longevity (Plemdat, 2018). In the cow index for Holstein, the same traits are included as in the sire index, except of productive lifetime (longevity) and conception rate. The future aim is to extend the scope for direct traits related to health (Czech Holstein Cattle Breeders' Association; personal communication). Some sub-indices for health and fitness in this population have been previously constructed; however, direct indicators for health have not been available in animal recording (Šafus et al., 2005), and only data from the literature have been used so far (Krupová et al., 2017).

Routine health trait monitoring has been ongoing for a few years, and the first estimates of genetic parameters for health traits were determined for the local population (Wolf et al., 2010; Zavadilová et al., 2015, 2017). The first Czech edition of the 'Claw Health Atlas' of ICAR (International Committee for Animal Recording) with a basic description and classification of the health diseases/disorders has been recently published (Šlosárková and Fleischer, 2017). Consequently, the direct incorporation of claw disease into the sire index for Holstein bulls has been investigated (Krupová et al., 2018).

The present study aimed to estimate genetic parameters for the new health traits and economic weights for all traits included in the breeding objective for Czech Holstein cows and to investigate the selection response for these traits when applying different sets of selection criteria in the cow selection index.

\section{Material and methods}

\section{Health traits}

The traits characterizing foot and claw health were overall foot and claw diseases (OCD) split up into infectious (CI) and non-infectious (CNI) diseases. The OCD in- 
cidence was defined as the number of foot and claw disease cases per cow and lactation at risk, including cases treated with and without antibiotics. CI diseases included dermatitis digitalis and interdigitalis, interdigital phlegmon and heel horn erosion; the CNI diseases included ulcers, white line disease, horn fissures, double sole and sole hemorrhage; and the OCD diseases comprised all the recorded disorders. The udder health trait was clinical mastitis incidence (CM), being defined as the number of veterinary-treated udder inflammations per cow and lactation. For economic evaluation, the OCD and CM incidence was further averaged over all lactations and expressed per year.

\section{Genetic parameters of health traits}

The characteristics (basic statistics, genetic parameters, breeding values) of traits already included in breeding objective and selection index were provided by the Czech and Moravian Breeders' Association. Genetic parameters of new health traits were directly estimated based on authors' dataset including genetic correlations between the selection index traits. The records of health traits were collected between 1999 and 2017 on seven Holstein farms that were willing to participate in the study. Holstein cows with at least $75 \%$ Holstein genes and known pedigree were included into the analysed dataset. The farms varied in size from 150 to 900 cows per herd (average 365). They were from distinct regions (Central Bohemian Region, Vysočina Region, Hradec Králové Region); however, all used the same management, feeding, and housing technology common in most dairy herds in the Czech Republic. Detection of CM by farmers was accomplished via visual examination of the udder or milk, and CM was treated with antibiotics prescribed by a veterinarian. Data for foot and claw disease/disorders were collected by hoof trimmers either during regular trimming or during emergency visit. In the Czech Republic, the whole herds are trimmed twice a year or the cow is trimmed during the dry period. In our dataset, almost half of records were made during emergency visits. Dataset used for genetic evaluation of health traits are presented in Table $1 \mathrm{a}, \mathrm{b}$.

Table $1 \mathrm{a}$. Number of observations and lactation incidence rate (LIR) for health traits ${ }^{1}$

\begin{tabular}{l|c|c|c|c}
\hline \multicolumn{1}{c|}{ Disease } & $\begin{array}{c}\text { No. } \\
\text { of disorders }\end{array}$ & $\begin{array}{c}\text { No. of lactations } \\
\text { with disease }\end{array}$ & $\begin{array}{c}\text { LIR } \\
\text { in \% }\end{array}$ & Heritability \\
\hline Overall foot and claw disease & 40354 & 12092 & 44.5 & $0.14 \pm 0.022$ \\
Infectious foot and claw disease & 16658 & 7022 & 14.2 & $0.10 \pm 0.021$ \\
Non-infectious foot and claw disorders & 17039 & 6663 & 23.0 & $0.13 \pm 0.019$ \\
Clinical mastitis & 34337 & 17527 & 36.6 & $0.07 \pm 0.015$ \\
\hline
\end{tabular}

'Values are taken from authors' datasets for the health traits (for more details see Material and methods section). LIR represents percentage of the affected lactations from the total number of lactations.

A linear animal model was employed to estimate genetic parameters and breeding values for health traits in DMU software (Madsen and Jensen, 2010) and it looked as: 
Table $1 \mathrm{~b}$. Number of lactations per parity ${ }^{1}$

\begin{tabular}{l|c|c|c|c|c|c|c}
\hline \multirow{2}{*}{ Parity } & \multirow{2}{*}{$\begin{array}{c}\text { Lactations } \\
\text { (n) }\end{array}$} & \multirow{2}{*}{$\begin{array}{c}\text { Average } \\
\text { age at calving } \\
\text { (days) }\end{array}$} & \multirow{2}{*}{$\begin{array}{c}\text { Age at calving } \\
\text { (days) } \\
\text { min-max }\end{array}$} & & \multicolumn{5}{|c}{ LIR in \% } \\
\cline { 5 - 9 } & & & & & OCD & CI & CNI \\
\hline 1st & 8437 & 784.4 & $600-1000$ & 29.61 & 44.81 & 31.60 & 13.76 \\
2nd & 6405 & 1197.9 & $1000-1693$ & 35.36 & 46.62 & 29.90 & 22.23 \\
3rd & 4290 & 1606.4 & $1326-2183$ & 41.45 & 55.06 & 32.14 & 32.45 \\
4th & 2314 & 2016.9 & $1663-2583$ & 48.14 & 65.73 & 34.36 & 44.94 \\
5th and further & 1369 & 2551.3 & $2031-3801$ & 62.30 & 70.34 & 35.57 & 52.59 \\
\hline
\end{tabular}

'Values are taken from authors' datasets for the health traits (for more details see Material and Methods section). LIR represents percentage of the affected lactations from the total number of lactations.

$\mathrm{CM}$ - clinical mastitis; OCD - overall foot and claw disease; CI - infectious foot and claw diseases; CNI non-infectious foot and claw disorders.

$$
\mathrm{y}_{i j k l m n o}=\mathrm{P}_{i}+\mathrm{H}_{j}+\mathrm{Y}_{k}+\mathrm{S}_{l}+\mathrm{AGE}_{m}+p e_{n}+a_{o}+e_{i j k l m n o}
$$

where:

$\mathrm{y}_{i j k l m n o}$ is the analysed binary health trait (CM, OCD, CI, and CNI) expressed as absence 0 or presence 1 of disease during lactation,

$\mathrm{P}_{i}$ is the fixed effect of parity class $i$ (5 levels: first, second, third, fourth, fifth plus later parities),

$\mathrm{H}_{j}$ is the fixed effect of herd $j$ (7 levels),

$\mathrm{Y}_{k}$ is the fixed effect of calving year $k$ (20 levels),

$\mathrm{S}_{l}$ is the fixed effect of calving season $l$ (4 levels: January - March; April - June; July - September; October - December),

$\mathrm{AGE}_{m}$ is the fixed effect of age at calving $m$ (13 levels),

$p e_{n}$ is the random effect of permanent environment $n$ (10 904 levels),

$a_{o}$ is the random additive genetic effect of animal $o$,

$e_{i j k l m n o}$ is the random residual effect.

The fixed effects in the model were included after preliminary analyses showed they had a statistically significant effect $(\mathrm{P}<0.01)$ on the health traits. The pedigree file included 26356 records.

Bivariate analyses were performed and (co)variance components and genetic correlations were estimated among all health traits. Fixed and random effects were the same as in the univariate model.

Genetic correlations between the health traits and the traits already included in the Holstein selection index were approximated by correlations between breeding values using Proc Corr (SAS, 2016). The genetic correlations were approximated because of the following reasons: first, the dataset for estimation of health traits included only small part of Holstein cattle population; second, the long period of monitoring does not guarantee that the direct estimation of genetic correlation reflects the actual genetic status of the population. 


\section{Economic weights for traits in the breeding objective for Czech Holstein cows}

The breeding objective traits of the Czech Holstein cows are listed in Table 2. Calf losses during rearing and age at first calving were considered to be direct traits (expressed only once in animal life); all other traits were considered to be maternal traits (expressed repeatedly in each cow parity). Although cows reach their mature weight only once, this weight influences feeding costs and revenues from culled cows repeatedly in different parities. The productive lifetime of cows is calculated mainly based on cow death and culling rates, and these two parameters occur also in each parity.

Table 2. Means, genetic standard deviations $(\mathrm{GSD})^{1}$ and marginal economic values $(\mathrm{EV})^{2}$ of actual and new $^{3}$ breeding objectives of Czech Holstein cattle

\begin{tabular}{lccccc}
\hline \multicolumn{1}{c}{ Trait (unit) } & Trait abbreviation & Mean & GSD & EV \\
\hline Milk yield/lactation (kg) & MY & 9546 & 741.59 & 0.101 \\
Milk fat content (\%) & \%F & 3.80 & 0.27 & 149.1 \\
Milk protein content (\%) & \%P & 3.34 & 0.145 & 309.3 \\
Conception rate of cows (\%) & CR & 91 & 2.54 & 5.64 \\
Service period (days) & SP & 127 & 5.00 & -0.018 \\
Losses of calves in rearing (\%) & LC & 5.4 & 2.0 & -1.03 \\
Age at first calving (days) & AFC & 765 & 10.0 & -0.064 \\
Mature weight of cows (kg) & MW & 635 & 25.0 & -0.68 \\
Productive lifetime of cows (years) & PL & 2.95 & 0.74 & 59.1 \\
Clinical mastitis (cases/year of risk) & CM & 0.98 & 0.10 & -87.9 \\
Claw disease (cases/year of risk) & CD & 1.00 & 0.054 & -76.3 \\
\hline
\end{tabular}

'Values are taken from the database of the Czech and Moravian Breeders' Association, the Holstein Cattle Breeders' Association (personal communication) and from authors' datasets for the health traits. Statistical parameters of new health traits were directly estimated based on authors' dataset.

${ }^{2} \mathrm{EVs}$ of the traits are expressed in $€$ per unit of the traits per cow per year and were calculated using production and economic parameters that were valid in the Czech Republic in $2017(1 €=100$ cents $=26.33 \mathrm{CZK})$.

${ }^{3}$ Claw disease incidence as the new trait is added among the breeding objectives in the current study.

Economic weight $\left(E W_{i j k}\right)$ of trait $i$ belonging to the trait group $j$ (maternal or direct traits) in the breeding objective for the selected animal group $k$ (dams) was calculated as a product of the marginal economic value of trait $i\left(E V_{i}\right)$ and the number of discounted gene expressions for the trait group $j$ and selected dam group $k\left(N D E_{j k}\right)$ :

$$
E W_{i j k}=E V_{i} N D E_{j k}
$$

The EVs and the NDEs for all traits were calculated using a bioeconomic model of dairy cattle production system with implemented gene-flow procedure for modelled pure-breeding system, which is implemented in the program EWDC, a part of the program package ECOWEIGHT (Wolf et al., 2013). The methods for the calculation of the EVs and the detailed definitions of all breeding objective traits have 
been described by Wolfová et al. (2007). For the description of the methods for the calculation of $N D E_{j k}$, see the report by Wolfová et al. (2005).

The base production and economic parameters applied for the calculation of the trait EVs has been described by Krupová et al. (2018). They represent the production and economic circumstances in the Czech Republic in 2017. When calculating the EV of claw health the most important losses were the additional costs related to treatment and medication (43\%) and losses due to discarded milk due to antibiotic treatment (57\%). The number of gene expressions for trait $i$ in all progeny groups coming from a selected cow in the age class 2 (i.e., the group $k$ consisted of two-year-old cows) were summed during the investment period of 25 years and were discounted to the year of cow selection with an annual discount rate of $2 \%$.

\section{Cow selection index and estimation of selection response}

The impact of adding the three foot and claw disease (CD) traits (OCD, CI, and $\mathrm{CNI}$ incidence) and one udder health trait (CM incidence) to the current selection criteria on the genetic selection response for $\mathrm{CD}$ and $\mathrm{CM}$ and on the total economic selection response and index reliability were investigated in the four variants of the selection index for Holstein cows:

1) Current index: actual index for Czech Holstein cows,

2) Health index: adding OCD (12\%) and CM (7\%) to the selection criteria,

3) Health index: adding CI (4\%), CNI (8\%), and CM (7\%) to the selection criteria,

4) Health index: adding OCD (7\%), CI (2\%), CNI (3\%), and CM (7\%) to the selection criteria.

In the health indices (index No. 2 to 4 ) the CD was added to the current breeding objectives. Through constructing all four selection indices, two scenarios were investigated for the relative weighting of the traits in the indices (for the values of coefficients $b$ ). In the first scenario, the ratios among the traits in the current index (No. 1) were considered for the new health indices (indices 2 to 4), making 19\% space for the new added traits (the trait proportion is given about). In the second scenario, the weighting factors (coefficients $b$ ) for the traits in all indices were calculated using the general principles of the selection index theory, i.e., through optimizing the total selection response in the breeding objective. The optimized indices 1 to 4 were labelled as 10 to 40 .

Through calculating the genetic selection responses in the breeding objective traits, four selection paths were considered (sires of sires, sires of dams, dams of sires, and dams of dams). The selection intensity was set to one, and the generation intervals for the four paths, the index accuracy and the estimated trait genetic standard deviations were further considered. Details for the calculation of selection response are presented in Krupová et al. (2018). The economic responses in the breeding objective traits were calculated by multiplying the genetic selection responses by the trait EW. 


\section{Results}

The estimated heritability of new health traits is given in Table $1 \mathrm{a}$ and varied from $0.07(\mathrm{CM})$ to 0.14 (OCD). The genetic standard deviations of the breeding objective traits are listed in Table 2. The estimates for the genetic correlations among the selection criteria in the comprehensive cow selection index 4 together with the reliability of the estimated cow breeding values for these criteria are given in Table 3. The genetic correlations between health traits and milk component traits (percentage of fat and protein) were favourable but very low for foot and claw disease incidences (from -0.01 to -0.07 , S.E. from 0.1566 to 0.0140 ) and somewhat higher for clinical mastitis (from -0.04 to -0.1 , S.E. from 0.0926 to 0.0836). As expected for the $\mathrm{CD}$ traits, the highest correlations were found between these traits and locomotion (LOC). Strong correlation coefficients were estimated between the infectious and non-infectious foot and claw diseases on the one hand and overall foot and claw diseases on the other hand $(0.69$ and 0.56$)$. Reliability of the estimated breeding values for the health traits were lower ( 0.64 to 0.68$)$ than that of the other traits $(0.70$ to 0.80 ) due to the number of records for health traits (Table $1 \mathrm{~b}$ ).

The marginal economic values for all breeding objective traits are listed in Table 2. These values are the same for both bulls and cows. Both were in the second age class i.e., the age for the bull and cow groups for which the NDEs were calculated was approximately 2 years. However, the number of discounted gene expressions (NDEs) differs between these groups. The NDEs for direct traits (losses of calves in rearing and age at first calving) were 1.56 for bulls and 1.84 for cows, whereas the NDEs for maternal traits (all other included traits) were 1.31 for bulls and 2.19 for cows. These differences in NDEs for direct and maternal traits caused differences in the EWs for the traits, as presented in Table 4 (the EWs of traits for bulls were taken from Krupová et al., 2018). The cow EW for CD incidence was $-168 €$ per case; this means that the present value of profit obtained within the time period of 25 years from the progeny of a cow, which would have breeding value for CD incidence by one case per year lower than other cows, will be $168 €$ higher than the profit from the progeny of the other cows. The cow EW for CM incidence was $-193 €$ per case.

Table 5 presents the expected annual genetic selection response for the cow breeding objective traits and the total annual economic response obtained using the current Holstein cow selection index and the different health indices. The selection response in the direct health traits was favourable in all variants of the health index. Reductions in the claw diseases (CD) and clinical mastitis (CM) were 0.003 to 0.005 and 0.004 to 0.006 cases per cow and year, respectively, using the health indices. Considering the optimized comprehensive index (index No. 4o) and the average herd size of the Czech Holstein cattle (280 cows; Holstein Cattle Breeders' Association, personal communication), the expected selection response in CD incidence would be -1.10 cases per herd per year, which is -5.19 cases of CD per herd per average generation interval of 4.7 years, leading to an increase in the present value of profit by $396 €$ per herd $(-76.3 € \times-5.19$ cases, see Table 2$)$ due to reduction in foot and claw diseases. 


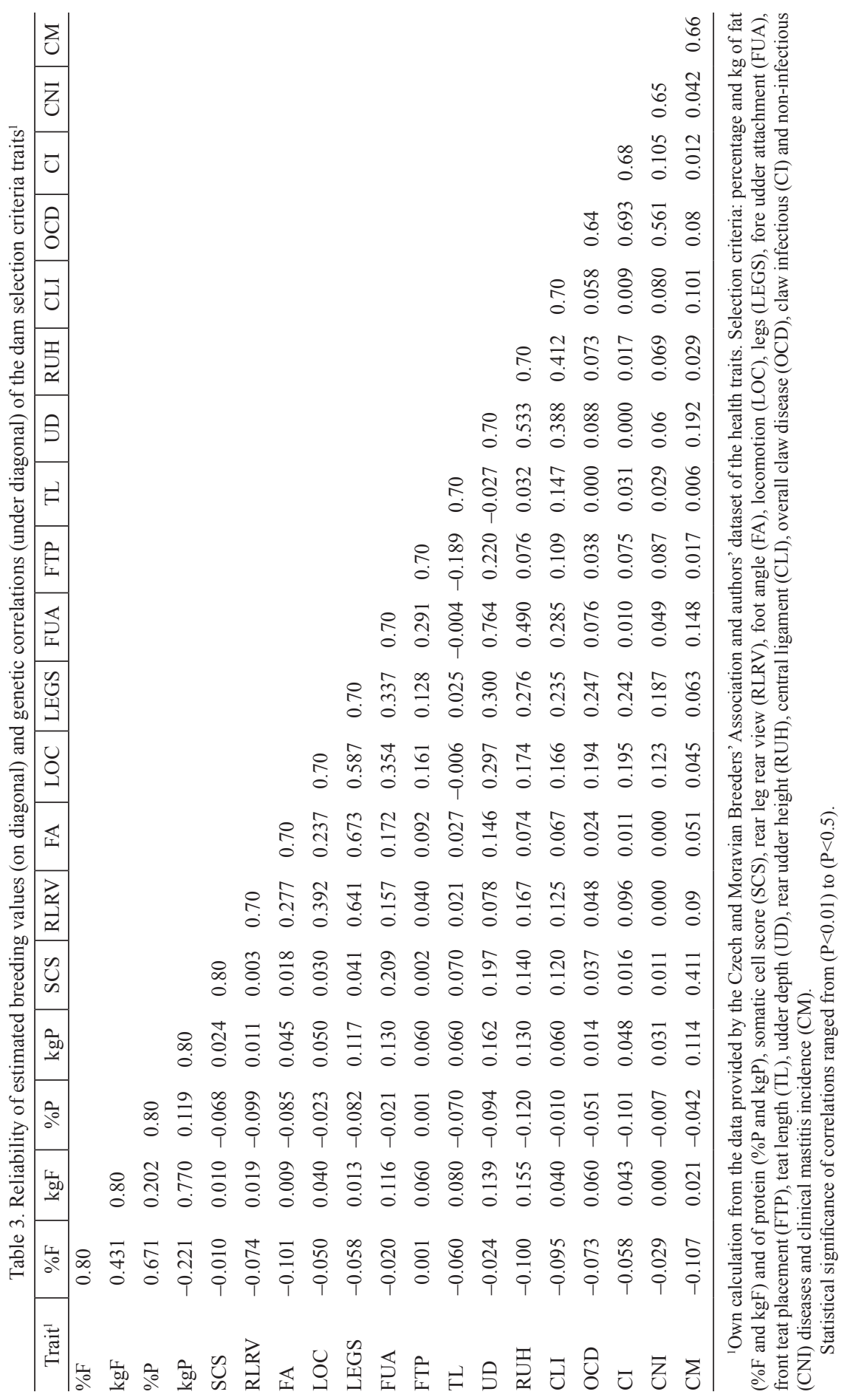


Table 4. Economic weights ${ }^{1}$ of the traits in the breeding objective of Czech Holstein cows $\left(\mathrm{EW}_{\mathrm{C}}\right)$ compared with the economic weights of traits in the breeding objective for Czech Holstein bulls $\left(\mathrm{EW}_{\mathrm{B}}\right)$

\begin{tabular}{lccccc}
\hline \multicolumn{1}{c|}{ Trait (unit) } & Trait & Type of the trait & $\mathrm{EW}_{\mathrm{C}}$ & $\mathrm{EW}_{\mathrm{B}}$ \\
\hline Milk yield/lactation (kg) & $\mathrm{MY}$ & $\mathrm{M}$ & 0.221 & 0.132 \\
Milk fat content (\%) & $\% \mathrm{~F}$ & $\mathrm{M}$ & 328 & 196 \\
Milk protein content (\%) & $\% \mathrm{P}$ & $\mathrm{M}$ & 680 & 406 \\
Conception rate of cows (\%) & $\mathrm{CR}$ & $\mathrm{M}$ & 12.4 & 7.40 \\
Service period (days) & $\mathrm{SP}$ & $\mathrm{M}$ & -0.040 & -0.024 \\
Losses of calves in rearing (\%) & $\mathrm{LC}$ & $\mathrm{D}$ & -1.90 & -1.61 \\
Age at first calving (days) & $\mathrm{AFC}$ & $\mathrm{D}$ & -0.116 & -0.098 \\
Mature weight of cows (kg) & $\mathrm{MW}$ & $\mathrm{M}$ & -1.498 & -0.894 \\
Productive lifetime of cows (years) & $\mathrm{PL}$ & $\mathrm{M}$ & 130 & 77.5 \\
Clinical mastitis (cases/year of risk) & $\mathrm{CM}$ & $\mathrm{M}$ & -193 & -115 \\
Claw disease (cases/year of risk) & $\mathrm{CD}$ & $\mathrm{M}$ & -168 & -100 \\
\hline
\end{tabular}

${ }^{1} \mathrm{EW}_{\mathrm{B}}$ of each trait is given in $€$ and express the change in profit (in all successive generations of bull progeny within an investment period of 25 years) that would be obtained from a single mating of a selected bull with the trait breeding value one unit higher than the average trait breeding value of the bull population. The change in profit in the successive generations was discounted to the year of bull selection with the annual discount rate of $2 \%$. The $\mathrm{EW}_{\mathrm{C}}$ of a trait has the same meaning, and it is related to a single mating of a selected cow.

${ }^{2} \mathrm{M}$ : maternal trait, D: direct trait.

Table 5. Genetic response ${ }^{1}$ and overall economic response for the actual and new ${ }^{2}$ breeding objectives and the index reliability

\begin{tabular}{l|c|c|c|c|c|c|c|c}
\hline \multirow{2}{*}{\multicolumn{1}{c}{ Trait (unit) }} & \multicolumn{7}{c}{ Genetic response for the index variant ${ }^{3}$} \\
\cline { 2 - 10 } & 1 & 10 & 2 & 20 & 3 & 30 & 4 & 40 \\
\hline Milk yield/lactation (kg) & 65.27 & 54.16 & 84.52 & 75.19 & 79.58 & 74.39 & 71.94 & 73.34 \\
Milk fat content (\%) & 0.012 & 0.025 & 0.010 & 0.010 & 0.015 & 0.011 & 0.011 & 0.010 \\
Milk protein content (\%) & 0.011 & 0.018 & 0.010 & 0.011 & 0.014 & 0.010 & 0.010 & 0.010 \\
Conception rate of cows (\%) & 0.004 & 0.012 & 0.025 & 0.029 & 0.030 & 0.027 & 0.024 & 0.026 \\
Service period (days) & -0.003 & -0.019 & -0.002 & 0.018 & 0.011 & 0.029 & 0.002 & 0.010 \\
Losses of calves in rearing (\%) & -0.009 & -0.019 & -0.009 & -0.009 & -0.013 & -0.009 & -0.009 & -0.009 \\
Age at first calving (days) & -0.063 & 0.068 & -0.014 & -0.002 & -0.039 & -0.008 & -0.020 & -0.012 \\
Mature weight of cows (kg) & 0.308 & -0.433 & 0.428 & 0.456 & 0.657 & 0.487 & 0.446 & 0.452 \\
Productive lifetime of cows (years) & 0.027 & 0.034 & 0.039 & 0.040 & 0.048 & 0.038 & 0.037 & 0.038 \\
Clinical mastitis (cases/year of risk) & -0.001 & -0.003 & -0.004 & -0.006 & -0.005 & -0.006 & -0.004 & -0.005 \\
Claw disease (cases/year of risk) & - & - & -0.004 & -0.004 & -0.005 & -0.003 & -0.004 & -0.004 \\
Economic response ${ }^{2}(€$ per year) & 29.11 & 37.96 & 34.68 & 33.18 & 39.83 & 33.26 & 31.62 & 32.30 \\
Index reliability (\%) & 52.9 & 61.5 & 57.3 & 58.3 & 55.9 & 57.8 & 56.3 & 57.0 \\
\hline
\end{tabular}

${ }^{1}$ Expressed in unit of the trait per year.

${ }^{2}$ Claw disease incidence as the new trait is added among the breeding objectives in the indices 2 to $4 \mathrm{o}$.

${ }^{3}$ Index variants: Index 1 represents the current selection index of cows; in indices 2 to 4 , the new traits (CM and three traits for CD incidence) were gradually added to the selection criteria. Indices designated with "o" considered the weighting of traits to reach the optimal selection response and index reliability, and for indices without "o", the trait weighting was taken from the current selection index of the Czech Holstein cattle (see Material and Methods for details). 
The reduction in $\mathrm{CM}$ was higher when the health index was optimized (i.e., in the indices 2o to 4o); for CD incidence, such an impact of the index optimization on selection response was not obtained. The reduction in CM, applying the current index without CD traits, was only 0.001 cases per cow and year. When constructing an optimized current index, a reduction in $\mathrm{CM}$ of 0.003 cases per cow and year was determined.

In all variants of the index, favourable annual genetic response was also found for the current breeding objective traits, except for cow mature weight. The annual selection responses for milk yield were between $54 \mathrm{~kg}$ (in optimized current index) to $85 \mathrm{~kg}$ (in non-optimized health index No. 2) and were always higher in non-optimized than in optimized indices. On the other hand, the annual selection responses in cow conception rate, service period and cow productive lifetime were mostly higher in the optimized variants of all indices than in non-optimized index variants. Favourable selection response for mature weight $(-0.433 \mathrm{~kg}$ per year) was determined only in the optimized current index No. 10.

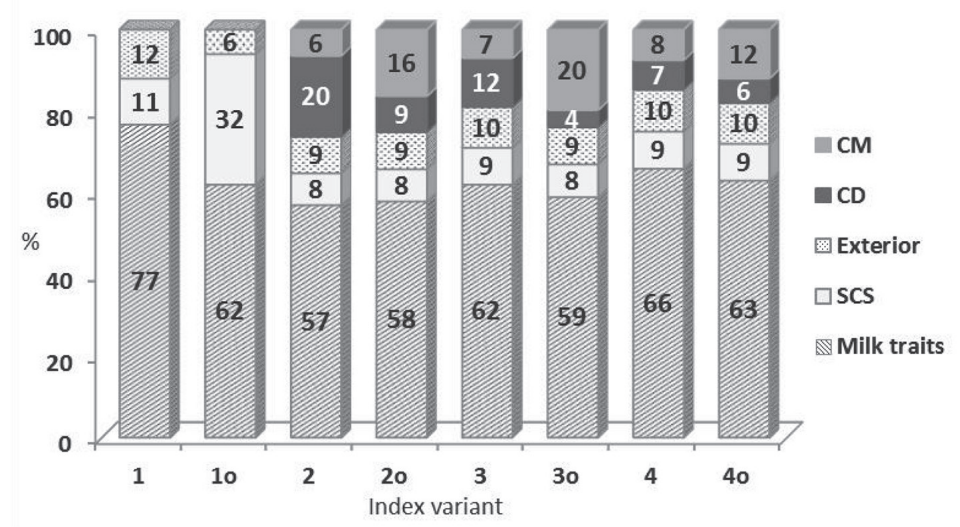

${ }^{1}$ Traits included in the groups of the selection criteria: milk traits $(\% \mathrm{~F}, \mathrm{kgF}, \% \mathrm{P}, \mathrm{kgP}), \mathrm{SCS}$ (somatic cells score), exterior (feet and legs - RLRV, FA, LOC, LEGS; udder - FUA, FTP, TL, UD, RUH, CLI), CD (OCD, CI, CNI) and CM (clinical mastitis incidence). Definition of the selection criteria is given in Table 3 and detailed description of the indices in Material and Methods.

${ }^{2} \mathrm{Claw}$ disease incidence as the new trait is added among the breeding objectives in the indices 2 to 40 .

Figure 1. Contribution of the groups of the selection criteria ${ }^{1}$ (in \%) to the overall selection response in the actual and new ${ }^{2}$ breeding objective using the indices 1 to $4 \mathrm{o}$

The total annual economic selection response applying non-optimized index was the lowest $(29 €)$ when using the current index and the highest $(40 €)$ in the health index with $\mathrm{CD}$ and $\mathrm{CM}$ incidences in the breeding objective and $\mathrm{CM}, \mathrm{CI}$, and $\mathrm{CNI}$ incidences in the index (index 3). For the optimized index variants, the highest total economic selection response $(38 €$ ) was obtained in the current index (including only the udder health traits, the CM incidence in the breeding objective and the SCS in the index) and the lowest ( $32 €$ ) in the health index No. 4o (with CD and CM in the breeding objective and with all the direct health traits, $\mathrm{CM}, \mathrm{OCD}, \mathrm{CI}$, and $\mathrm{CNI}$ in the 
index). The index reliability for the optimized variant of the current index $(61.5 \%)$ was higher than that for the optimized health indices (57 to 58\%) due to lower reliability of the estimated breeding values for the new health index traits $(0.64$ to 0.68 , see Table 3$)$ than for the current index traits $(0.70$ to 0.80$)$.

The contributions of the selection index trait groups to the total economic selection response in the breeding objective for Holstein cows for the investigated index variants are presented in Figure 1. The most important information sources were milk production traits (contributing to the total selection response from $77 \%$ in index 1 to $57 \%$ in index 2), followed by the indirect health trait somatic cell score in index $10(32 \%)$ or the direct health traits in indices 2 to 4 (15 to $26 \%)$.

\section{Discussion}

\section{Cow direct health traits}

The udder, foot and claw diseases of cows have been of high interest in recent animal research because of the increased occurrence of these diseases in dairy cow herds and their high impact on the economic efficiency of dairy farms. Many studies have reported that $40 \%$ to $70 \%$ of cows exhibit foot and claw diseases/disorders in dairy herds (e.g., Buch et al., 2011; Chapinal et al., 2013; van der Spek et al., 2013). Heringstad et al. (2003) reported that values for CM lactation incidence in Norwegian dairy cattle were $15 \%, 19 \%$, and $24 \%$ for the first, second and third lactation, respectively. Kadarmideen and Pryce (2001) observed that 17\% was the average value for lactation CM incidence in Holstein herds in the UK; however, they reported large differences among individual farms, ranging from $0.5 \%$ to $57 \%$.

In our datasets for udder health, the average lactation incidence of CM over all involved farms was $38.8 \%$, ranging from $34.3 \%$ to $51.4 \%$ in individual farms and from $29.6 \%$ in the first lactation to $62.3 \%$ in lactations higher than 5 . At least once in their lifetime, $61 \%$ of all controlled cows exhibited a foot and claw disorder, and $43 \%$ of all observed lactations were affected. In Czech Holstein herds, the frequency of claw diseases often exceeds 50\%; based on the assumption of the Holstein Cattle Breeders' Association, their incidence in the whole population is almost 1 case per lactation. Therefore, this mean value was applied when calculating the economic weight of the trait CD (Table 2). This value can be easily updated in the future when the incidence for the whole population will be available.

To incorporate the udder and foot and claw health traits into the dairy cattle breeding objective and/or selection indices, genetic parameters were estimated in many studies (van der Linde et al., 2010; Buch et al., 2011). The heritability of the $\mathrm{CM}$ incidence that has been estimated in the current literature ranged from 0.001 to 0.10 (Martin et al., 2018), the highest estimates were determined using threshold models. Genetic parameters for the CM incidence estimated in the present study for Czech Holstein cattle lay within this range. For the foot and claw diseases and disorders that were expressed as grouped traits, the heritability estimates were reported to be 0.02 to 0.12 (Heringstad et al., 2018); the highest estimates were determined using 
threshold models. Our estimates of these genetic parameters for OCD, CI, and CNI in Czech Holstein cattle were higher, ranging from 0.10 to 0.14 , probably due to the structure of datasets and compact pedigree.

\section{Selection indices and selection response}

The expected selection responses in the direct foot-and-claw health trait (CD) were favourable in all investigated variants of the Holstein cow health selection index (Table 5). Therefore, as recommended by other authors as well (e.g., Heringstad et al., 2018), the direct health traits should be added to the total merit indices with sufficient weighting coefficients to enable genetic improvement in these traits. In general, the annual genetic gain of the health traits calculated in our study was comparable with literature resources (Koenig et al., 2005; van der Linde et al., 2010; Šafus et al., 2005). Positive responses to selection for mastitis resistance have also been achieved in all Nordic countries using the total merit indices (Philipson and Lindhé, 2003). In contrast, Stott et al. (2005) found no favourable (slightly positive) selection responses for mastitis and lameness incidence ( 0.002 cases per year in both traits) in UK dairy herds, even if lifespan, milk somatic cells and locomotion were incorporated into the UK profit index. It can be assumed that direct selection with more information regarding udder and claw health traits would lead to a favourable gain. In our case, the selection focused only on one health trait (CM or OCD) would not lead to the indirect response in the second one due to the weak genetic correlation.

Through constructing the comprehensive health indices of cows in our study (index 2 to 4 vs. index 1), the index reliability improved (i.e., accuracy of animal selection increased by approximately 4 percentage points). Furthermore, the expected selection response in the current breeding objective traits also increased (e.g., responses for milk yield improved by $8 \mathrm{~kg}$, for productive lifetime by 0.011 years, and for cow conception rate by $0.022 \%$ ). This was confirmed in other studies (Martin et al., 2018), particularly for functional traits such as fertility and longevity. Productive lifetime and conception rate of cows are not included among the index selection criteria for the Czech Holstein cows. Therefore, adding the health traits to the breeding objective and to the index appears to be a valuable tool for the genetic improvement of cow longevity and conception rate until a direct selection of cows for these functional traits is possible. In the previous investigation of selection responses for breeding objective traits of Czech Holstein bulls, where these two traits were included in the index (Krupová et al., 2018, index 2 with CM and CD traits added to the current index), the expected annual genetic gain was $0.22 \%$ and 0.08 year for cow conception rate and productive lifetime, respectively. This result is markedly higher than the expected response for the same traits in cows $(0.026 \%$ and 0.038 years; see the comprehensive index in Table 5). Similarly, Stott et al. (2005) calculated the selection gain for cow longevity to be 0.036 vs. 0.000 lactations for updated dairy index, when lifespan was used as selection criterion. Therefore, in the future, direct selection for such functional traits could be beneficial for the local Czech Holstein cow population due to addition of a substantial amount of information and improvement in the selection response and accuracy. 
Philipson and Lindhé (2003) reported that giving more emphasis on functional traits instead on production traits will contribute to a higher total economic response (increases by $10 \%$ to $20 \%$ were obtained in the reviewed publications). This observation was confirmed in our study, in which the addition of the direct health traits into selection criteria increased the total economic response by approximately $6 \%$.

We expect that the increase in the quantity of the health data collected through the "Diary of diseases and medication", which was developed for local cattle farmers in previous years (Šlosárková et al., 2017), will increase the reliability of breeding value and correlation estimates for health traits. Moreover, genomic evaluation of the female dairy population (calves, heifers and cows) has started in last months in the Czech Republic to enhance the reference populations as it is also recommended by Heringstad et al. (2018) due to lack of bulls with high-reliability traditional evaluations.

Based on our study, it can be concluded that through considering direct health traits in a selection index for the Czech Holstein cows, a rapid progress could be achieved in the reduction of incidence of claw, foot, and udder diseases, and a higher response could be expected for other functional traits, maintaining the positive gain in production traits that are currently included in the cow breeding objective. The index variant 3 or 4, in which clinical mastitis and infectious and non-infectious foot and claw diseases were added to the current cow Holstein index, should be applied in the practice because of the higher reliability of estimated breeding values for these traits compared to the trait of overall foot and claw disease. Furthermore, cow longevity and conception rates are recommended to be included into the cow selection criteria to enhance the favourable gain in these functional traits.

\section{Acknowledgements}

The authors would like to thank the Holstein Cattle Breeders' Association in the Czech Republic for their helpful comments and discussion. The study was funded by the Ministry of Agriculture of the Czech Republic MZE-RO0718 V003 and QJ1510144.

\section{References}

B u ch L.H., Søre n s e n A.C., L a s s e n J., B e rg P., Eri k s s o n J.A., J a k ob s e n J.H., S ør e n s e n M.K. (2011). Hygiene-related and feed-related hoof diseases show different patterns of genetic correlations to clinical mastitis and female fertility. J. Dairy Sci., 94: 1540-1551.

Cha pinal N., Ko e ck A., S ew a le m A., Kelton D.F., Mas on S., Cramer G., Miglior F. (2013). Genetic parameters for hoof lesions and their relationship with feet and leg traits in Canadian Holstein cows. J. Dairy Sci., 96: 2596-2604.

Greenough P.R., Weaver A.D., Broom D.M., Ess lemont R.J., Galindo F.A. (1997). Basic concepts of bovine lameness. In: Lameness in Cattle, P.R. Greenough and A.D. Weaver (eds). 3rd Edition. Philadelphia, W.B. Saunders. pp. 3-13.

Heringstad B., Klementstal G., Steine T. (2003). Selection responses for clinical mastitis and protein yield in two Norwegian dairy cattle selection experiments. J. Dairy Sci., 86: 2990-2999.

Hering st a d B., Egger - D a n n e r C., Charfed d in e N., Pryce J.E., S to c k K.F., K o fle r 
J., S o g s t a d A. M., Holzhau e r M., Fi ed le r A., M üller K., Ni els en P., Thomas G., Gengler N., de Jong G., Ødegård C., Malchiodi F., Miglior F., Alsa od M., Cole J.B. (2018). Invited review: Genetics and claw health: Opportunities to enhance claw health by genetic selection. J. Dairy Sci., 101: 1-21.

K a d a r m i d e e n H.N., P r y c e J.E. (2001). Genetic and economic relationships between somatic cell count and clinical mastitis and their use in selection for mastitis resistance in dairy cattle. Anim. Sci., 73: 19-28.

Kargo M., Hjortø L., Toivon en M., Eriks s o n J.A., A a mand G.P., P ed e r s en J. (2014). Economic basis for the Nordic total merit index. J. Dairy Sci., 97: 7879-7888.

Koenig S., Sharifi A.R., Wentrot H., Landmann D., Eis e M., Simianer H. (2005). Genetic parameters of claw and foot disorders estimated with logistic models. J. Dairy Sci., 88: 3316-3325.

K r u p ová Z., Př i b y 1 J., K r u pa E., Wo 1 fová M. (2017). Claw disease incidence as a new trait in the breeding goal for the Czech Holstein population. Agric. Conspec. Sci., 82: 235-239.

Krupová Z., Wolfová M., Krupa E., Přibyl J., Zavadilová L. (2018). Claw health and feed efficiency as new selection criteria in the Czech Holstein cattle. Czech J. Anim. Sci., 63: 408-418.

M a d s e n P., J e n s e n J. (2010). DMU - a package for analysing multivariate mixed models, Version 6, release 5.0. Aarhus University, Foulum, Denmark, http://dmu.agrsci.dk/

Mart in P., B ark e ma H.W., B ri to L.F., N a r y a n a S.G., M ig l i or F. (2018). Novel strategies to genetically improve mastitis resistance in dairy cattle. J. Dairy Sci., 101: 2724-2736.

Phili p s on J., Li ndhé B. (2003). Experiences of including reproduction and health traits in Scandinavian dairy cattle breeding programmes. Livest. Prod. Sci., 83: 99-112.

Plemdat (2018). Výpočet selekčního indexu pro býky a plemenice holštýnského plemene (in Czech). 3 p., http://iserv.plemdat.cz/cz/pages/SIH.pdf

SAS (2016). Release 9.4 (TS1M1) of the SAS $®$ System for Microsoft ${ }^{\circledR}$ Windows ${ }^{\circledR}$. SAS Institute, Inc., Cary, USA.

Š a fu s P., Ští p k ová M., S tá d ník L., Přib y l J., Č e r mák V. (2005). Sub-indexes for bulls of Holstein breed in the Czech Republic. Czech J. Anim. Sci., 50: 254-265.

Šl o sárk ová S., F le i s cher P. (2017). ICAR atlas zdraví paznehtů (in Czech). ICAR Technical Series, 45 p., https://www.icar.org/wp-content/uploads/2017/10/Czech-translation-of-the-ICAR-Claw-Health-Atlas.pdf

Šl os árková S., F le i s cher P., P e chová A., Háje k M., Li povs ky D., Zava di lová L., $\mathrm{K}$ a š ná E., S t a n ě k S. (2017). Internationally compatible on-line recording of dairy cattle diseases and treatments in the Czech Republic. Proc. XVII Middle European Buiatrics Congress, Štrbské Pleso - High Tatras, ECBHM, p. 142-143.

S t o t $t$ A.W., C offey M.P., B r others t o n e S. (2005). Including lameness and mastitis in a profit index for dairy cattle. Anim. Sci., 80: 41-52.

van der Linde C., de Jong G., Koenen E.P.C., Eding H. (2010). Claw health index for Dutch dairy cattle based on claw trimming and conformation data. J. D a i r y S c i ., 93: 4883-4891.

van der Spek D., van Arendonk J.A., Vallée A.A., Bovenhuis H. (2013). Genetic parameters for claw disorders and the effect of preselecting cows for trimming. J. Dairy Sci., 96 : 6070-6078.

Wolf J., Wolfová M., Štíp k ová M. (2010). A model for the genetic evaluation of number of clinical mastitis cases per lactation in Czech Holstein cows. J. D a i r y Sci., 93: 1193-1204.

Wolf J., Wolfová M., Krupa E. (2013). User's Manual for the Program Package ECOWEIGHT (C Programs for Calculating Economic Weights in Livestock), Version 6.0.4. Part 1: Programs EWBC (Version 3.0.4) and EWDC (Version 2.2.3) for Cattle. Institute of Animal Science, Prague, Czech Republic, https://www.researchgate.net/publication/323497082

Wolfová M., Wolf J., Přibyl J., Zahrádková R., Ki c a J. (2005). Breeding objective for beef cattle used different production systems. I. Model development. Livest. Prod. Sci., 95: 201-215.

Wolfová M., Wolf J., Kvapilík J., Ki c a J. (2007). Selection for profit in cattle. I. Economic weights for purebred dairy cattle in the Czech Republic. J. Dairy Sci., 90: 2442-2455.

Zavadilová L., Štípková M., Š ebková N., Svitáková A. (2015). Genetic analysis of clinical mastitis data for Holstein cattle in the Czech Republic. Arch. Tierzucht, 58: 199-204. 
Zavadilová L., Štípková M., Svitáková A., Krupová Z., Kašná E. (2017). Genetic parameters for clinical mastitis, fertility and somatic cell score in Czech Holstein cattle. Ann. Anim. Sci., 17: 1007-1018.

Received: 12 XII 2018

Accepted: 21 V 2019 